\title{
The effect of feeding a natural feed additive on the performance of broiler chickens
}

\author{
Natalya Yurina ${ }^{1,2, *}$, Boris Khorin $^{1}$, Denis Yurin $^{1}$, Marina Semenenko ${ }^{1}$ and Elena \\ Kuzminova $^{1}$ \\ ${ }^{1}$ Krasnodar Research Centre for Animal Husbandry and Veterinary Medicine, 4, Pervomaiskaya Str., \\ Znamensky village, Krasnodar, 350055, Russia \\ ${ }^{2}$ Kuban State Agrarian University named after I.T. Trubilin, 13, Kalinina Str., Krasnodar, 350000, \\ Russia
}

\begin{abstract}
Natural feed additive is made on the basis of bottom sediments of the steppe reservoirs of the Krasnodar Territory and is a dry powder of a grayish tint. Mineralization of local bottom sediments is $6.5 \mathrm{~g} / \mathrm{kg}$, calcium content is $29.7 \mathrm{~g} / \mathrm{kg}$, macronutrients - from 1.04 to $25.8 \mathrm{~g} / \mathrm{kg}$, trace elements from 0.03 to $0.7 \mathrm{~g} / \mathrm{kg}$. The medium reaction is from neutral to slightly alkaline. Using sapropel feed additives (SFA), it was possible to increase the gross live weight gain of broiler chickens by $1.7-2.0 \%$ while reducing feed costs per $1 \mathrm{~kg}$ of gain by $0.5 \%$. All internal organs of the poultry were developed within normal limits. There was profitability increase by $1.1 \%$ in growing broilers, when using sapropel feed additives in full feed. Blood biochemical values were at an optimal level. Therefore, this feed additive can be considered as a natural feed ingredient; however, it is necessary to further develop a complex feed additive from natural components that partially or completely meets the requirement of the poultry in biologically active substances and micronutrients.
\end{abstract}

\section{Introduction}

Issues affecting the feeding area in the context of intensification of the poultry industry are very relevant today. In this regard, an important area of research is the search for cheaper unconventional and available feed products that will increase the productivity of poultry and reduce the cost of production.

The issue of providing feed for livestock farms is the main one in the system of production of full-fledged livestock products and determining in the formation of a pricing policy for it. In feed formulas, made according to generally accepted technology, the proportion of grain components is more than $70 \%$, which are comparable to components suitable for human nutrition. Along with this, there are huge reserves of little-used or completely unused natural sources that can combine a complex of biologically active substances and are constantly being renewed. However, in their natural state, most natural sources are incompatible with the technologies of traditional feed production because of their physical and mechanical properties (liquid, viscous) and, in addition, they are

*Corresponding author: naden8277@mail.ru 
characterized by low feed value. Therefore, the problem of finding new and alternative ways to use natural feed products, improving their quality while reducing the cost of producing feed, is relevant and is one of the main for the agricultural sector of the economy. One of the possible ways to optimize the feeding of poultry is to search for natural, effective and cheap ingredients based on sapropel [1-5].

In the Krasnodar Territory, there are large deposits of natural feed raw materials bottom sediments, which can be successfully used as raw materials for the manufacture of feed additives.

Scientists from other regions of our country conducted tests with silt deposits as a feed additive for farm animals, while receiving positive results.

The scientific development of the practical use of lake bottom sediments (sapropels) in feeding poultry as a new feed additive in the conditions of the Krasnodar Territory is very urgent due to the strong siltation of the region's water bodies, which can simultaneously improve its ecological state $[6,7]$.

The study of the possibility of using silt lake sediments as a feed additive for agricultural animals and poultry is also relevant in the aspect that at the present stage there is a massive siltation of lakes. Due to the strong siltation of fresh water bodies in the Krasnodar Territory, their recharge with underground keys becomes minimal. Because of the dozens of dams, the rivers have been turned into weakly interconnected ponds, and in the hot season the water almost does not reach the mouth. Even if you look at the problem exclusively from an economic point of view, the use of natural lake deposits can be environmentally competently combined with deepening the bottom of water bodies and subsequent extraction of silts, while determining the purpose of its application [8-11]. Eutrophication of water bodies has become one of the most serious threats to aquatic ecosystems in the world, especially for water quality, and in the future may have a negative impact on public health. With combined factors of climate change and human activities, eutrophication has expanded from shallow lakes in the temperature zone to water lakes in cold areas. Due to the natural eutrophication of lakes and rivers, as well as anthropological activity, a large number of bottom sediments appear; water bodies decompose and turn into swamps. There are many ways to reduce siltation of lakes and rivers - to carry out mechanical cleaning. However, currently there is a problem of utilization of sapropels. Therefore, the use of bottom sediments for feed purposes is a very relevant topic [12-15].

\section{Materials and methods}

The objective of the research was to study the possibility of feeding sapropel feed additives in different dosages in feed for broiler chickens.

To achieve the goal, the following tasks were set and solved:

1. To study the safety, dynamics of live weight and weight gain by the growth periods of broiler chickens when feeding the studied feed additive;

2. To determine the palatability and feed costs per $1 \mathrm{~kg}$ of live weight gain in the poultry;

3. To study the formation of meat productivity of broiler chickens;

4. To analyze the biological status of poultry in the study of feeding SFA.

5. To calculate the economic efficiency of the data obtained in the experiment.

According to the Methodological Recommendations for Scientific Research on the Feeding of Farm Poultry (2000), scientific experiment was carried out to determine the rate of SFA in diets for broiler chickens at the Kavkaz poultry farm in the Dinskoy district of the Krasnodar Territory.

Sapropelic feed additive (SFA) is made on the basis of bottom sediments of steppe water bodies of the Krasnodar Territory and is a dry powder of a grayish tint. The mineralization of local bottom sediments is $6.5 \mathrm{~g} / \mathrm{kg}$, the calcium content is $29.7 \mathrm{~g} / \mathrm{kg}$, 
macronutrients - from 1.04 to $25.8 \mathrm{~g} / \mathrm{kg}$, trace elements from 0.03 to $0.7 \mathrm{~g} / \mathrm{kg}$. The reaction of the medium is from neutral to slightly alkaline.

Three groups of Cobb-500 cross-breed broiler chickens kept in cage batteries were selected for the experiment by the pair-analogue method. The microclimate of the room, the front of feeding and watering corresponded to the recommended parameters. The duration of the experiment was 42 days.

In the scientific and economic experiment, the following indicators were taken into account: poultry safety (as a percentage of the initial number); live weight of the chickens (by individual weighing at different periods of rearing); feed intake (by weighing feed residues). Biochemical blood tests were performed on an automatic analyzer - Vitalab Selectra Junior with software version 1.0. (open system for photometric tests, manufactured by Vital Scientific N. V. Netherlands) using reagents from ELITech Clinical Systems (France) and Analyticon biotechnologies AG (Germany).

The obtained digital material was processed by the biometric method of variation statistics according to N.P. Plokhinsky (1970). The differences were considered statistically significant when: * $-\mathrm{P} \leq 0.05 ; * *-\mathrm{P} \leq 0.01 ; * * *-\mathrm{P} \leq 0.001$.

The scheme of scientific and economic experiment was as follows $(n=50)$ : the first (control) group received complete feed $(\mathrm{CF})$, the second $-\mathrm{CF}+0.75 \%$ SFA by weight of feed, the third - CF $+1.5 \%$ SFA by weight of feed.

According to the periods of growing, the diet of broiler chickens was completely balanced in all components.

\section{Results}

As a result of scientific and economic experiment, it has been found that the highest safety of chickens was in the experimental groups - $96.0 \%$, in comparison with the control $88.0 \%$.

Table 1 shows the change in live weight of broiler chickens by growing periods.

Table 1. Dynamics of live weight of chickens, $g(n=50)$.

\begin{tabular}{|l|c|c|c|}
\hline \multirow{2}{*}{\multicolumn{1}{|c|}{ Items }} & \multicolumn{3}{c|}{ Group } \\
\cline { 2 - 4 } & \multicolumn{1}{|c|}{ Live weight (g) by periods (days): } \\
\hline 1 & $42.4 \pm 0.43$ & $42.1 \pm 0.39$ & $\mathbf{3}$ \\
\hline 7 & $164.6 \pm 2.66$ & $180.7 \pm 2.73^{* * *}$ & $185.8 \pm 2.49^{* * *}$ \\
\hline in \% to control & 100.0 & 109.8 & 112.9 \\
\hline 14 & $472.1 \pm 8.25$ & $485.7 \pm 7.05^{*}$ & $497.1 \pm 7.33^{* *}$ \\
\hline in \% to control & 100.0 & 102.8 & 105.3 \\
\hline 28 & $954.3 \pm 16.59$ & $948.2 \pm 15.84$ & $966.2 \pm 15.51$ \\
\hline in \% to control & 100.0 & 99.4 & 101.2 \\
\hline 35 & $1436.0 \pm 24.80$ & $1428.9 \pm 21.14$ & $1454.9 \pm 22.22$ \\
\hline in \% to control & 100.0 & 99.5 & 101.3 \\
\hline 42 & $1975.0 \pm 34.11$ & $2006.8 \pm 28.85$ & $2012.4 \pm 28.27$ \\
\hline in \% to control & 100.0 & 101.6 & 101.9 \\
\hline $\begin{array}{l}\text { Gross weight gain for the } \\
\text { experiment, g }\end{array}$ & 1932.6 & 1964.7 & 1969.8 \\
\hline $\begin{array}{l}\text { Average daily weight gain } \\
\text { for the whole experiment, } \mathrm{g}\end{array}$ & 46.0 & 46.8 & 46.9 \\
\hline in \% to control & 100.0 & 101.7 & 102.0 \\
\hline
\end{tabular}

Note: $* \mathrm{P} \leq 0.05 ; * * \mathrm{P} \leq 0.01 ; * * * \mathrm{P} \leq 0.001$. 
On the 7th day of growing, the live weight of chickens significantly increased in the second and third groups by $9.8(\mathrm{P} \leq 0.001)$ and $2.8 \%(\mathrm{P} \leq 0.001)$.

On the 14th day of the scientific and economic experiment, the live weight of broiler chickens in the second group increased by $2.8 \%(\mathrm{P} \leq 0.05)$, and in the third - by $5.3 \%$ $(\mathrm{P} \leq 0.01)$.

The increase in live weight of chickens in the first half of the experiment suggests that the use of SFA as a component of compound feeds gives a good start for the growth of young animals due to the biologically active substances contained in this raw material.

By the $28^{\text {th }}$ day of growing, there was a tendency to increase the live weight of the third experimental group by $1.2 \%$. In the second experimental group, the increase in live weight was significantly lower by $0.6 \%$. On the $35^{\text {th }}$ day of the experiment, in the third group, the dynamics of an increase in live weight by $1.3 \%$ compared to the control is also visible, and in the second - an unreliable decrease by $0.5 \%$.

Gross weight gain for the entire experimental period in the control group reached $1932.6 \mathrm{~g}$; in the second experimental group - $1964.7 \mathrm{~g}$ and in the third $-1969.8 \mathrm{~g}$.

The average daily increase in the control group for the whole experimental period was $46.0 \mathrm{~g}$, in the second experimental group - $46.8 \mathrm{~g}$, or $1.7 \%$ higher than in the control, in the third experimental group - $46.9 \mathrm{~g}$, or $2.0 \%$ higher. Therefore, SFA can be used as a feed component, since it has a positive effect on the increase in live weight of the poultry.

Over the whole reference period, the chickens consumed 3.64; 3.67 and $3.68 \mathrm{~kg}$ of feed according to the groups, however, the costs per $1 \mathrm{~kg}$ of live weight gain in the experimental groups were $1.87 \mathrm{~kg}$, which is $0.5 \%$ lower than in the control.

At the end of the experiment, a control slaughter of the chickens was carried out, the results of which are presented in table 2 .

Table 2. Results of control slaughter $(n=50)$.

\begin{tabular}{|l|c|c|c|}
\hline \multicolumn{1}{|c|}{ Indicators } & \multicolumn{3}{|c|}{ Group } \\
\cline { 2 - 4 } & $2385 \pm 37$ & $2513,5 \pm 199.5$ & $\mathbf{2}$ \\
\hline $\begin{array}{l}\text { Pre-slaughter live } \\
\text { weight, g }\end{array}$ & $1690.5 \pm 62.5$ & $1712.5 \pm 112.5$ & $1854 \pm 174$ \\
\hline $\begin{array}{l}\text { Weight of dressed } \\
\text { chicken, g }\end{array}$ & 74.5 & 73.6 & 73.6 \\
\hline Slaughter yield, \% & 758.5 & 785.0 & 837.5 \\
\hline Weight of muscles, g: & $413 \pm 12$ & $415.5 \pm 15.5$ & $25 \pm 240.5$ \\
\hline pectoral & 24.4 & 24.3 & $209 \pm 35$ \\
\hline $\begin{array}{l}\text { in \% to the weight of } \\
\text { dressed chicken }\end{array}$ & $206.5 \pm 5.5$ & $214 \pm 9$ & 11.3 \\
\hline femoral & 12.2 & 12.5 & $153.5 \pm 10.5$ \\
\hline $\begin{array}{l}\text { in \% to the weight of } \\
\text { dressed chicken }\end{array}$ & $139 \pm 8$ & $155.5 \pm 12.5$ & 8.3 \\
\hline drumsticks & 8.2 & 9.0 & $33.0 \pm 5.0$ \\
\hline $\begin{array}{l}\text { in \% to the weight of } \\
\text { dressed chicken }\end{array}$ & $37.0 \pm 7.0$ & $41.5 \pm 0.5$ & 89.2 \\
\hline $\begin{array}{l}\text { Weight of internal fat, } \\
\text { g }\end{array}$ & 100.0 & 112.2 & \\
\hline in \% to control & & & \\
\hline
\end{tabular}

Note: $* * \mathrm{P} \leq 0.01$

From the data obtained it can be seen that there has been a tendency to increase the preslaughter live weight of the chickens of the experimental groups by 5.4 and $6.9 \%$, respectively. 
It should be noted a significant increase in pectoral muscle weight in the third experimental group by $15.0(\mathrm{P}<0.01) \%$. In the second group, there is a dynamics of an increase of this indicator by $0.6 \%$.

Slaughter muscle yield in both experimental groups increased by $0.9 \%$ compared to the control.

There was a tendency to increase the output of the pectoral muscles of the experimental groups by $0.1-1.2 \%$ and the lower leg muscles by $0.1-0.8 \%$.

The dynamics of an increase in the output of the femoral muscles by $0.3 \%$ was observed in the second group of the experiment and in the third - it was insignificantly reduced by $0.9 \%$.

The weight of the internal fat in the second group of the experiment insignificantly increased by $12.2 \%$, and in the third - it insignificantly decreased by $10.8 \%$.

During the control slaughter, the weight of the internal organs of broiler chickens was determined. The results are presented in table 3.

Table 3. The weight of the internal organs of broiler chickens, $g(n=50)$.

\begin{tabular}{|l|c|c|c|}
\hline \multicolumn{1}{|c|}{ Items } & \multicolumn{3}{c|}{ Groups } \\
\cline { 2 - 4 } & $\mathbf{1}$ & $\mathbf{2}$ & $\mathbf{3}$ \\
\hline Weight of dressed chicken, g & $2130.5 \pm 54.5$ & $2194 \pm 158$ & $2291.5 \pm 204.5$ \\
\hline Glandular stomach & $7.3 \pm 0.3$ & $7.3 \pm 0.3$ & $7.1 \pm 0.2$ \\
\hline $\begin{array}{l}\text { in \% to the weight of not-dressed } \\
\text { chicken }\end{array}$ & 0.34 & 0.33 & 0.31 \\
\hline Gizzard stomach & $30 \pm 2$ & $34 \pm 2$ & $32 \pm 2$ \\
\hline $\begin{array}{l}\text { In \% to the weight of not-dressed } \\
\text { chicken }\end{array}$ & 1.41 & 1.55 & 1.40 \\
\hline Intestines & $125.5 \pm 4.5$ & $120.5 \pm 15.5$ & $99 \pm 3^{* * *}$ \\
\hline $\begin{array}{l}\text { in \% to the weight of not-dressed } \\
\text { chicken }\end{array}$ & 5.89 & 5.49 & 4.32 \\
\hline Liver & $45 \pm 3$ & $42.5 \pm 0.5$ & $47 \pm 3$ \\
\hline $\begin{array}{l}\text { in \% to the weight of not-dressed } \\
\text { chicken }\end{array}$ & 2.42 & 2.35 & 2.23 \\
\hline Heart & $15.5 \pm 2.5$ & $11.0 \pm 2,0$ & $12.0 \pm 0.1$ \\
\hline $\begin{array}{l}\text { in \% to the weight of not-dressed } \\
\text { chicken }\end{array}$ & 0.73 & 0.50 & 0.52 \\
\hline
\end{tabular}

Note: $* * * \mathrm{P} \leq 0.001$

All internal organs of the chickens developed within normal limits. It should be noted a significant decrease in the weight of the intestines of the chickens in the third group of the experiment by $21.1(\mathrm{P}<0.001) \%$, which is possibly associated with an increase in the chyme passage.

All blood serum indicators of broiler chickens in the scientific and economic experiment were within the physiological norm and did not have significant deviations in groups, which indicates a balanced feeding of young chickens and their good health.

It should be noted that in the second group of broiler chickens, the serum glucose content decreased by $13.1 \%(\mathrm{P} \leq 0.05)$, and the amount of phosphorus increased by $9.4 \%$ in the second group $(\mathrm{P} \leq 0.01)$, and by $15.2 \%$ in the third group $(\mathrm{P} \leq 0.001)$. There was a tendency to increase the calcium content in the blood serum of chickens in the experimental groups - by $1.7-2.2 \%$, lower cholesterol - by $10.3-14.2 \%$

The obtained data on the activity of AST and ALT enzymes showed that there was no negative effect of SFA in the studied doses on the broiler chickens: there was a tendency to a decrease in AST activity in the experimental groups by $1.8-2.1 \%$, ALT by $3.3 \%$ in second group. In the third group, ALT activity decreased by $5.0 \%$, compared with the control $(\mathrm{P} \leq 0.05)$. 
The inclusion of the studied feed additive in the feed for broilers practically did not affect the cost of the diet. Production costs per head in the third experimental group were higher than in the control by 1.7 rubles, for the entire period of the experiment. The cost of $1 \mathrm{~kg}$ of live weight gain in the second and third groups was lower by only $0.8 \%$, compared with the control. However, due to the increase in the cost of gross production in the second and third experimental groups of chickens, the profit was gained by 2.0 and 2.1 rubles / head, respectively, in comparison with the control. According to the calculations of economic indicators, it was found that the profitability of broiler rearing, when using sapropel feed additives in full feed, increased by $1.1 \%$, compared with the control.

\section{Conclusions}

Using sapropel feed additives (SFA), it was possible to increase the gross live weight gain of broiler chickens by $1.7-2.0 \%$ while reducing the feed costs per $1 \mathrm{~kg}$ of weight gain by $0.5 \%$. Therefore, it is possible to consider a sapropelic feed additive as a natural feed ingredient; however, it is necessary in the future to develop a complex feed additive from natural components that partially or completely meets the requirements of chickens in biologically active substances and micronutrients.

\section{References}

1. Z. Lu, A. Thanabalan, H. Leung, R. Akbari Moghaddam Kakhki, R. Patterson, E.G. Kiarie, Poultry Science 98, 6411-6421 (2019) doi: 10.3382/ps/pez479

2. W. Siegert, T. Zuber, V. Sommerfeld, J. Krieg, D. Feuerstein, U. Kurrle, M. Rodehutscord, Poultry Science 98, 5700-5713 (2019) doi: 10.3382/ps/pez355

3. Yefei Zhou, Shanguo Mao, Meixian Zhou, Poultry Science 98, 2790-2799 (2019) doi: 10.3382/ps/pez071

4. Shu-Biao Wu, R.A. Swick, J. Noblet, N. Rodgers, D. Cadogan, M. Choct, Poultry Science 98, 1222-1234 (2019) doi: 10.3382/ps/pey442

5. O.O. Babatunde, A.J. Cowieson, J.W. Wilson, O. Adeola, Poultry Science 98, 67426750 (2019) doi.org/10.3382/ps/pez390

6. N. Labutina, D. Osepchuk, D. Yurin, Amazonia Investiga 8(20), 668-673 (2019)

7. N. Yurina, S. Kononenko, A. Vlasov, A. Danilova, A. Gneush, Journal of Pharmaceutical 10(7), 1860-1862 (2018)

8. G.A. Leonova, V.A. Bobrov, S.K. Krivonogov, A.A. Bogush, V.A. Bychinskii, A.E. Mal'tsev, G.N. Anoshin, Russian Geology and Geophysics 56, 745-761 (2015) doi: org/10.1016/j.rgg.2015.04.006

9. I. Belyuchenko, Nauchnyi zhurnal KubGAU 106(2), 772-793 (2015) http://ej.kubagro.ru/2015/02/pdf/48.pdf

10. N. Naumova, T. Nechaeva, N. Smirnova, Y. Fotev, V. Belousova, Asian Journal of Soil Science and Plant Nutrition 1(3), 1-11 (2017) doi: 10.9734/AJSSPN/2017/35760

11. A. Rizhinashvili, Management of Environmental Quality: An International Journal 28(1), 120-136 (2017) doi: 10.1108/MEQ-09-2015-0170

12. N.V. Zaimenko, N.P. Didyk, N.A. Pavliuchenko, B.O. Ivanytska, I.P. Kharytonova, N.V. Rositska, Journal of Crop Improvement 32(4), 1-20 (2018) doi: 10.1080/15427528.2017.1405856 
13. V.D. Strakhovenko, O.P. Taran, N.I. Ermolaeva, Russian Geology and Geophysics 55(10), 1160-1169 (2014) doi: 10.1016/j.rgg.2014.09.002

14. L. Grantina-Ievina, A. Karlsons, U. Andersone-Ozola, G. Ievinsh, ZemdirbysteAgriculture 101, 355-366 (2014) doi: 10.13080/z-a.2014.101.045

15. A.A. Bogush, G.A. Leonova, S.K. Krivonogov, V.A. Bobrov, V.D. Tikhova, L.M. Kondratyeva, A.E. Kuzmina, A.E. Maltsev, Procedia Earth and Planetary Science 7, 81- 84 (2013) doi: 10.1016/j.proeps.2013.03.161 